\title{
Study on Integrated Competency-based Accounting Education
}

\author{
Qiuling Zhao \\ Accounting School \\ Harbin University of Commerce \\ Harbin, China
}

\begin{abstract}
Globalization and rapid developments of new Economics has led to dramatic changes in the business environment, the gap between the competencies employers expected and perceived accounting graduates to possess has been widening. Based on a review of the literature, a framework of integrated competency-based education system is proposed for bridging the gap, which comprises three components: core competencies, broad business competencies and accounting \& finance competencies. To build the integrated competency, the accounting educators need to reshape their teaching and learning approach, adopt more creative teaching pedagogies and integrate these pedagogies with series of accounting courses
\end{abstract}

Keywords-integrated competency; core skills; accounting curriculum; accounting pedagogy; problem-based learning

\section{INTRODUCTION}

Higher education provides students with opportunities to learn and acquire knowledge, skills, and attitudes. What is to be learned and how it is learned, is usually pre-determined based on the designed accounting curriculum system. With the rapid increase globalization and new Economics trends, business environments become more complex, therefore, graduates have to constantly improve their current skills and acquire new ones. However, the traditional knowledge-based accounting curriculum system does not necessarily equip students with the skills required to apply the content in the global business environments. The higher education institutions should develop the integrated competency-based education system. To understand the new accounting curriculum system, it is necessary to understand the trends of the higher education purpose and identify the critical skills that graduates must acquire.

\section{ShIFT OF ACCOUNTING EdUCATION PURPOSES}

Brooks (2014) posits that there are three conflicting views about the purpose of higher education :(1) the moral purpose. (2) The cognitive/intellectual purpose. (3) The commercial purpose. Only a hundred years ago, the purpose of higher education was to teach values and morals. By the early-to-mid twentieth century the prevailing purpose has shifted to an intellectual purpose around a core of great works of Western Civilization. To the present, in 1971, approximately $75 \%$ of freshmen believed that the purpose of higher education was to develop a "meaningful philosophy of life" (the cognitive approach).

By 2011, almost $80 \%$ of freshmen stated that the purpose was to become "very well off financially" (Berrett, 2015). Recently the governors of Wisconsin are launching the Wisconsin Idea to replace the University of Wisconsin's mission from "search for truth" to "meeting the state's workforce needs" (Evans, 2015).

In short, because of the rapidly growing changes in the business environment and the slow changes in the accounting education curriculum, there has been an increasing gap between acquirements and requirements for the graduates... So, what are the critical skills for students to learn in order to succeed in the rapidly changing business environments?

In 2009, The Economist surveyed 349 executives from all over the world. $90 \%$ of them identified organizational agility as a "core differentiator in today's rapidly changing business environment" (Economist Intelligent Unit, 2009). To improve the organizational agility, the employee should own the core competency that includes adaptability, creativity, a passion for learning, and an ability to acquire new information.

Moss (2012) and Friedman, Hampton-Sosa (2013) cite a survey of 225 employers conducted by Millenial Branding and Experience Inc. that found the five major traits employers seek are communication skills (98\%), having a positive attitude (97\%), being adaptable to change (92\%), having teamwork skills (92\%), and being goal oriented $(88 \%)$.

Friedman (2014) cites that Google is moving away from "traditional metrics" and seeking skills that include "leadership, humility, collaboration, adaptability, and loving to learn and relearn".

Adams(2014) cite the National Association of Colleges and Employers (NACE) survey and found that employers cared more about skills such the ability work in teams and solve problems than in a major per se. The top five competencies on the follow list were of particular value to employers, so if a student can demonstrate that $\mathrm{s} / \mathrm{he}$ has acquired them, the specific major will be of lesser importance. 
- Ability to work in a team structure

- Ability to make decisions and solve problems (tie)

- Ability to communicate verbally with people inside and outside an organization

- Ability to plan, organize and prioritize work

- Ability to obtain and process information

With a careful review of these critical skills needed, to a surprising degree, it turns out that employers seek cognitive proficiency and a solid grounding in values and morality even more than they seek functional proficiency. In fact college degrees, majors, and GPAs are becoming less meaningful to the corporate world (Friedman, 2013). Employers are less concerned with the specialized major but care greatly about the set of skills a potential employee possesses (Weinreichian, 2014).

\section{INTEGRATED COMPETENCY-BASED FRAMEWORK OF ACCOUNTING EDUCATION}

It is necessary to reshape traditional knowledge-based accounting education system, the revised framework of higher education focus on the critical skills instead of specialty. A Integrated competency-based framework for accounting education is presented in "Fig. 1".This Framework comprises three main (and interconnected) components: accounting \& finance competencies, broad business competencies and core competencies.

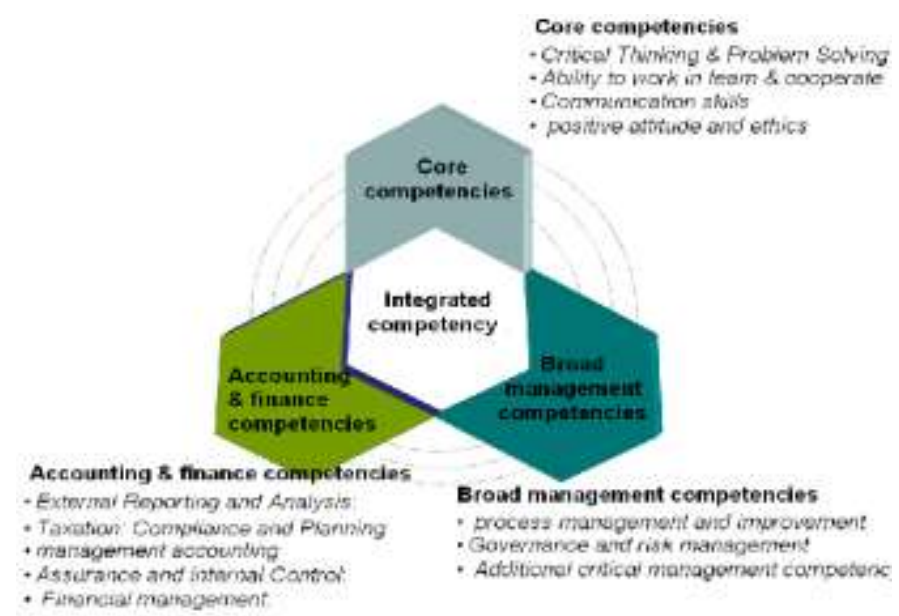

Fig. 1. Integrated competency-based framework of accounting education.

\section{A. Broad Business Competencies}

In addition to the in-depth knowledge in a specialized area, accounting graduates should also have a wider spectrum of knowledge in multidisciplinary areas. The Framework presented in Figure 1 identifies three categories of broad business competencies: process management \& improvement, corporate governance \& risk management and additional critical management skills.

Process management \& improvement: As the part of the strategy-implementation process, it includes management of organization value chains, design, management and improvement of key processes, development and management of customer relationships etc. Accounting and finance professionals should be competent in and use the organization's value chain to effectively and efficiently satisfy customer and other stakeholder requirements.

Governance and risk management: It includes corporate governance, enterprise risk management (ERM), and compliance activities associated with applicable laws, regulations, contracts, strategies, and organizational policies which inter-dependencies among core management responsibilities and practices.

Additional critical management competency: It includes human resource management, operations management, marketing, information technology, economics, business law, mergers and acquisitions, and globalization. Among others, if the professionals work in multidisciplinary teams. In order to solve diverse and unstructured problems in unfamiliar settings, they must have an understanding of the political, economic, social, cultural, and psychological Forces that affect organizations.

\section{B. Accounting \& Finance Competencies}

Accounting \& finance competencies enable graduates to integrate management and special analytical methods for assisting an enterprise to formulate and execute its strategy successfully. These competencies are depicted in the framework as consisting of five dimensions: external reporting and analysis, management accounting, taxation, assurance $\&$ internal control and finance.

External Reporting and Analysis: External reporting (including related internal reports) is focused on conveying financial and non-financial information to various external stakeholders in accordance with reporting standards. Accountants should be able to prepare and analyze external reports to enhance the usefulness of these reports

To intended users.

Taxation: Compliance and Planning: All accountants must understand the basics of taxation to be able to assess tax impacts of decisions and to know to seek expert advice where appropriate (Dennis-Escoffier et al. 2009). It includes require knowledge and skills to offer advice on tax-planning and to compute tax liabilities in routine and non-routine situations, Analyzing, assessing and advising on tax liabilities or assets and tax consequences.

Management accounting: Accountants must be able to use accounting concepts and methods to identify, evaluate, choose and achieve options that best support the organization's strategic and operational goals. It include Planning, Analysis and Control functions

Assurance and Internal Control: Accounting and financial professionals in all types of organizations must understand the role of assurance and apply the principles of internal control. As a professional practice, Assurance require extensive knowledge, skills, industry expertise, and experience in assurance applied to various subject matters for 
entities. Internal Control is a process designed and performed to provide reasonable assurance regarding the effectiveness and efficiency of operations, the reliability of financial reporting, and compliance with laws and regulations.

Financial management: To be a role of financial manager, graduates need develop the knowledge and skills relating to issues affecting investments, financing, and dividend policy decisions. Possess the capacity of applying working capital management techniques, effective investment appraisal, identify and evaluate alternative sources of business finance and apply risk management techniques in business.

\section{Core Competencies}

The core competencies are deemed necessary for all collegiate graduates. However, it is not easy for students to develop these critical skills and depend on the deeply learning of the other competencies .Figure 1 presents four core competencies: Critical Thinking \& Problem Solving; Ability to work in team \& cooperate; Communication skills and positive attitude $\&$ ethics

Critical Thinking \& Problem Solving : the ability of a graduate to raise vital questions to collect accurate and complete information, analyze the problems using logical reasoning, apply the problem-solving methodologies to real world business problems and anticipating problems, finding acceptable solutions, developing inductive thought processes, and assigning priorities (Simons and Higgins, 1993).

Ability to work in team \& cooperate: the ability to be a productive member of a team is vital in almost every occupation. It is the social sensitivity of group members rather than their intelligence that makes a group more effective than the sum of its constituent's .this is the reason that the "ability to collaborate and cooperate" is indispensable skills.

Communication skills: the skills include listening effectively, presenting, and defending views orally and in writing, and locating and organizing information from both human and electronic sources (Simons and Higgins, 1993). The ability for graduates to communicate in common global languages, negotiation skills, working in team environments using new communication technologies has become a necessity.

Positive attitude and ethics: They play a key role in the career of the practitioners; People with a positive attitude work well with others and know how to deal with customers. Any organizations want to hire employees with a "Positive attitude and empathy." Employees that have integrity will put in an honest day's work, while unethical employees can cause all kinds of legal problems and potential loss for companies.

As portrayed in Figure 1, the accounting graduates arise from their ability to bring their core competencies based on the deeply learning and mastery of specialist competencies and broad business competencies.

\section{INTEGRATION OF PEDAGOGY AND ACCOUNTING CURRICULUM}

According to above analysis, mastering the core competencies is the key path for graduates being successful in the future career. However, it is impossible to attain the core competencies through the traditional teacher-centered and contents-focused learning approach.

So, the first rising to challenge for the accounting educators is reshaping the teaching \& learning approach, which includes changing the emphasis from teacher-centered to learner-centered, "knowing that" to "knowing how" , personal to interpersonal skills, intellectual orientation to action orientation, problem-making to problem-solving, knowledge-based to task-based and proposition-based learning to experiential learning (Barnett, Parry \& Coate,2001).

In addition, accounting Instructors need adopt more creative teaching pedagogies and integrate these pedagogies with series of accounting courses. The integration matrix of Pedagogy and accounting curriculum is described in "Fig. 2'. The branches of accounting curriculum included financial accounting (FA), management accounting (MA) Auditing(AU), taxation(TX) and financial management(FM) represent the $\mathrm{X}$ variables, while the several pedagogies recommended by researchers to improve the effectiveness in delivering the accounting curriculum represent the $\mathrm{Y}$ variables.

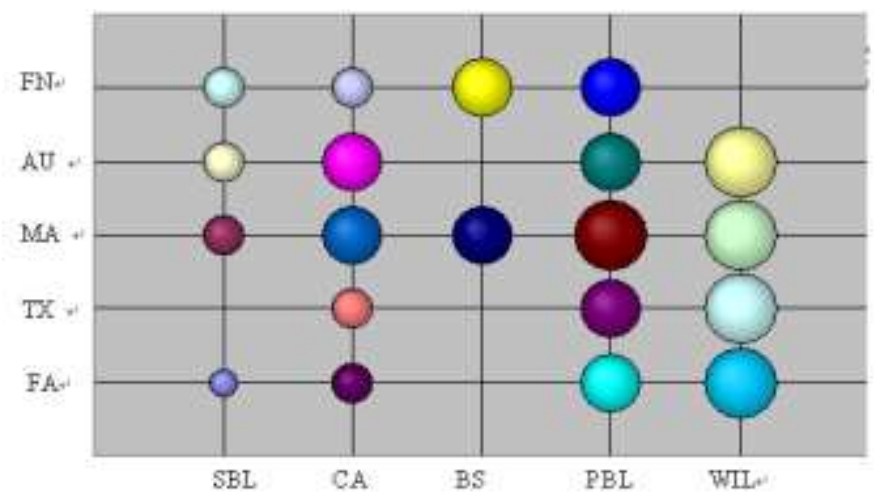

Fig. 2. Integration matrix of Pedagogy and accounting curriculum.

1) Software-based Learning(SBL) approach: Software has been certainly an essential and basic element in all accounting courses. the SBL approach apply to the series of financial accounting(FA), Auditing(AU), management accounting(MA) and financial management(FM). for example, the students are required to prepare full sets of accounts using accounting software, conduct audit on the computerized case study given and master the enterprise resource planning (ERP) system to manage internal and external resources including tangible assets, financial resources, materials, and human resources that related to the MA and FM courses. By implementing software-based learning, students will experience hands-on exposure in accounting software and spreadsheets which are essential 
tools in their profession. As technical courses, it's learning objective and contents are simple and level of the learning difficulty is low. It is benefit for the board business and professional competencies.

2) Case approach $(C A)$ : Case Approach(CA) is the most recommended teaching pedagogy for accounting \&finance subjects. the CA may apply to all kinds of courses ,however, application in MA and FM courses take good effect which attained multiple objectives. having given the hands-on opportunity to diagnose real issues faced by a business entity, Students are often driven to read, understand, analyze information extracted from a comprehensive case prescription, and subsequently report research findings and discussions by applying knowledge acquired. the integration of the case-based learning will strengthen students' skills in solving unstructured problems, as it requires the exploration of multiple learning resources, application of theories acquired into the given problem, fosters critical thinking and strength the communication skill.

3) Problem-Based Learning (PBL): Problem-Based Learning (PBL) is the general problem-solving skills that were specifically taught and the emphasis on small-group and student-centered in the context of realistic cases, PBL is best implemented only after students possessing a basic knowledge of the courses. Due to the varied nature of PBL implementation, each institution would have to identify and clarify their learning objectives and implementation standards. It may apply to the high level course of FA, MA and TA.

4) Business simulation (BS):Business simulation (BS) immerses group-based students in the life of an evolving business environment, for which they are trained to develop continuing stream of business strategies backed by accounting principles. "Emphasizing communication information extraction, dialogue and collaborative problem solving are incorporated. IT skills, alternative viewpoints, and the effect of assumptions on decisions, the simulation episodes demonstrate the usefulness and importance of accounting to business decision makers" (Springer \& Borthick, 2004) . In the implementation of "Sandbox simulation training" in FM courses and "Business simulation challenge" for the senior business students, Results from their study showed that the simulated production process has immensely improved the students' level of understanding of the topic, and also provided inexperienced students with a feel of the real-life working experience.

5) Work-integrated learning(WIL): Work-Integrated Learning(WIL) is a complex curriculum approach that involves designing, implementing, and monitoring activities that integrate theoretical learning with practical application in the workplace. WIL is seen as meeting the demands of both employers and students for employability knowledge and skills (Patrick etal. 2009). Internships, service learning and practicum have been the primary WIL models. it may apply to the high level course of FA, AU ,TA and MA.

\section{CONCLUSION}

Mastering the core competencies is the key path for graduates being successful in the future career. What we need to do firstly is reshaping the teaching \& learning approach, which includes changing the emphasis from teacher-centered to learner-centered, "knowing that" to "knowing how", personal to interpersonal skills, intellectual orientation to action orientation, problem-making to problem-solving, knowledge-based to task-based and proposition-based learning to experiential learning.

\section{REFERENCES}

[1] Berrett, D. (2014, November 14). Now everything has a learning outcome. Chronicle of Higher Education, A31.

[2] Berrett, D. (2015, January 30). The day the purpose of college changed. Chronicle of Higher Education, A18- A21.

[3] Brooks, D. (2014a, September 9). Becoming a real person. New York Times, A29.

[4] Brooks, D. (2014b, November 28). The ambition explosion. New York Times, A31

[5] Apostolou, B., J. M. Hassell, J. E. Rebele, and S. F. Watson. 2010. Accounting education literature review (2006-2009). Journal of Accounting Education, 28 (3-4): 145-197.

[6] Apostolou, B., J. W. Dorminey, J. M. Hassell, and S. F. Watson. 2013 Accounting education

[7] Pathways Commission, The. 2012. Charting a National Strategy for the Next Generation of Accountants. American Accounting Association and American Institute of CPAs.

[8] Davies, M. (2000). Using a computerized case study to teach computer auditing: the reasons, the approach and the student response, Managerial Auditing Journal, Jul 2000, Vol. 15 Issue. 5, pp 247 252

[9] Hansen, J. D. (2006). Using Problem-Based Learning in Accounting,, Journal of Education for Business; Mar/Apr 2006 vol. 81, issue 4, p 221

[10] Springer, C. W. and Borthick, A. F. (2004). Business Simulation to Stage Critical Thinking in Introductory Accounting: Rationale, Design, and Implementation, Issues in Accounting Education Aug 2004, vol. 19, Issue 3, pg 277

[11] Abeysekera, I. (2008). Preferred learning methods: A comparison between international and domestic accounting students. Accounting Education: An International Journal, 17187-198.

[12] Abhayawansa, S., \& Fonseca, L. (2010). Conceptions of learning and approaches to learning A phenemenographic study of a group of overseas accounting students from Sri Lanka. Accounting Education: An International Journal, 19(5), 527-550. 